\title{
PERJUANGAN PEREMPUAN MERAIH KEMANDIRIAN DALAM RUANG SOSIAL STUDI ATAS NOVEL MIDAH SIMANIS BERGIGI EMAS KARYA PRAMODYA ANANTA TOER
}

\author{
M. Imam Sofwan Yahya \\ Fakultas Ilmu Kebudayaan, Universitas Indonesia \\ Jl. Prof. Dr. Selo Soemardjan Kampus Universitas Indonesia, Depok \\ Email:imamsofvan@gmail.com
}

\begin{abstract}
The struggle of women gain independence in the social space studies on novel Midah simanis gold teeth Pramodya work Ananta Toer. This article analyzes the novel Midah Simanis Gold Teeth by Pramoedya Ananta Toer using elements of narrative theory and the concept of Pierre Bourdieu on social room, arena, capital, habitus and distinction, discusses the process of Midah leaders struggle to achieve independence in the social space. The results showed that although Midah received discriminatory treatment in the social space, both private and public, he was able to perform a variety of operations and strategies by optimizing and developing its capitals to achieve success and independence of life.
\end{abstract}

\begin{abstract}
Abstrak. Perjuangan perempuan meraih kemandirian dalam ruang sosial Studi atas novel midah simanis bergigi emas karya pramodya ananta toer. Artikel ini menganalisis novel Midah Simanis Bergigi Emas karya Pramoedya Ananta Toer menggunakan teori unsur-unsur naratif dan konsep Pierre Bourdieu tentang ruang sosial, arena, kapital, habitus, dan distinction, membahas proses perjuangan tokoh Midah untuk mencapai kemandirian dalam ruang sosial. Hasil penelitian menunjukan bahwa walau Midah mendapat perlakuan diskriminatif dalam ruang sosial, baik privat maupun publik, ia mampu melakukan berbagai usaha dan strategi dengan mengoptimalkan dan mengembangkan kapital-kapital yang dimilikinya demi meraih keberhasilan dan kemandirian hidup.
\end{abstract}

Kata kunci: Pierre Bourdieu, ruang sosial, kapital, habitus, diskriminasi, perjuangan perempuan.

Kehidupan Pramoedya saat masih bersama orangtuanya di Blora, Jawa Tengah, serta pengalaman hidupnya bersama orang-orang yang tersingkir dan tertindas membekas serta diterjemahkan dalam karya-karyanya, sehingga inti dari karya-karya Pramoedya adalah menceritakan perjuangan hidup rakyat seharihari yang sering terkekang (August Hans den Boef dan Kees Snoek, 2008: vii). Kaum tertindas atau terkekang dalam pandangan Pramoedya tidak melulu menyangkut persoalan imperialisme antar-bangsa atau penguasa dan rakyat, tetapi juga antara dua jenis mahluk manusia, yaitu laki-laki dan perempuan. Stereotip umum tentang perempuan yang masih dianggap "kelas dua" dan selalu dikekang oleh lelaki mendapat perhatian Pramoedya dalam karya-karyanya. Sosok ibu dan nenek Pramoedya yang berkarakter kuat dan mandiri dalam kehidupannya menjadikan Pramoedya lelaki yang keras menentang diskriminasi terhadap kaum perempuan, sekaligus mendorong mereka bergerak dan berkarya dalam kehidupan. Dan Gadis Pantai serta Nyai Ontosoroh merupakan salah satu bukti keberpihakannya kepada perempuan yang dituangkan dalam karya sastra.

Gadis Pantai! Dia merupakan sosok seorang wanita yang mandiri. Dia tidak pernah menggantungkan diri pada orang lain. Bahkan pekerjaan yang paling kasar pun dia kerjakan sendiri [...] Selama masa penahanan saya di pulau Buru saya menciptakan sosok Nyai Ontosoroh. Itu terjadi sewaktu para penjaga batalion Pattimura membunuh sebelas tawanan sekaligus [...] Saat itulah muncul sosok Nyai Ontosoroh, untuk memberikan 
contoh kepada rekan sesama tawanan mengenai perjuangan seorang perempuan yang dapat membela dirinya dari kekuatan penjajah seorang diri. Dan hal itu berhasil, cerita tersebut diceritakan dimana-mana (August Hans den Boef dan Kees Snoek, 2008: 115).

Karya lain Pramoedya yang berlatar kisah perjuangan perempuan terkekang adalah novel Midah, Simanis Bergigi Emas. Novel ini pertama kali diterbitkan tahun 1954 oleh NV Nusantara. Kemudian diterbitkan kembali oleh Lentera Dipantara dan cetakan kelimanya terbit Februari 2010. Novel ini menceritakan tokoh utama bernama Midah yang berkarakter kuat dalam menghadapi segala bentuk kekerasan dan diskriminasi ruang sosial, yang sekaligus menjadi pelecut dalam melakukan perlawanan dan perjuangan hidup, sehingga menjadi seorang perempuan yang bebas, mandiri, dan sukses. Oleh karena itu, artikel ini mencoba untuk menganalisis ruang sosial serta strategi perjuangan tokoh utama dengan kapital dan habitus yang dimilikinya dalam meraih kebebasan dan kemandirian dalam perjalanan kehidupannya.

\section{Habitus, Kapital, Arena, dan Distingsi}

Konsep yang akan digunakan dalam dalam membahas novel ini adalah teori sosial yang dikemukakan Pierre Bourdieu yang mencakup habitus, kapital, arena atau ruang sosial, serta distinction. Secara literer, habitus berasal dari bahasa Latin yang berarti kondisi, penampakan atau situasi yang tipikal atau habitual, khususnya pada tubuh (Jenkins, 2010:107). Habitus sebagaimana dinyatakan Bourdieu dalam Outline of a Theory of Practice adalah:

system of durable, transposable dispositions, structured structures predisposed to function as structuring structures, that is, as principles which generate and organize practices and representations that can be objectively adapted to their outcomes without presupposing a conscious aiming at ends or an express mastery of the operations necessary in order to attain them. Objectively "regulated" and "regular" without being in any way the product of obedience to rules, they can be collectively orchestrated without being the product of the organizing action of a conductor (Bourdieu, 1977:72).

Berdasakan kutipan di atas, habitus dapat dimaknai sebagai kecenderungan atau kebiasaan yang terbatinkan dan melekat dalam diri dan bisa berubah-ubah yang mampu mempengaruhi praktik dan tindakan tanpa mengharuskan adanya kesadaran. Habitus juga besifat ganda, yaitu dihasilkan dari keadaan sosial, tetapi juga bias membentuk struktur kehidupan sosial. Menurut Haryatmoko, habitus adalah hasil keterampilan yang menjadi tindakan praktis yang tidak selalu harus disadari. Kemudian diterjemahkan menjadi sesuatu kemampuan yang kelihatannya alamiah dan berkembang dalam lingkungan sosial tertentu (Haryatmoko, 2010: 14).

Kapital adalah sekumpulan sumber daya yang dapat digunakan oleh pelaku atau agen dalam ruang sosial. Hal ini sejalan dengan yang diutarakan Bourdieu mengenai kapital dalam The Field of Cultural Reproduction, yaitu: "the inherited assets which define the possibilities inherent in the field" (1993:150). Bourdieu membagi kapital atau modal dalam empat kategori:

These fundamental social powers are, according to my empirical investigations, firstly economic capital, in its various kinds; secondly cultural capital or better, informational capital, again in its different kinds; and thirdly two forms of capital that are very strongly correlated, social capital, which consist of resources based on connections and group membership, and symbolic capital, which is the form the different types of capital take once they are perceived and recognized as legitimate (Bourdieu, 1993:69-70).

Kapital menurut Bourdieu ada empat macam, yaitu kapital ekonomi, budaya, sosial, dan simbolik. Kapital ekonomi adalah sumber daya yang bisa menjadi sarana produksi dan sarana finansial. Kapital budaya mencakup keseluruhan kualifikasi intelektual yang dapat diproduksi melalui pendidikan formal maupun warisan keluarga, seperti pengetahuan, kekayaan budaya (buku, karya seni), dan gelar pendidikan. Kapital sosial merupakan jaringan hubungan 
sebagai sumber daya yang dimiliki pelaku (individu atau kelompok) dalam hubungan dengan pihak lain yang memiliki kuasa untuk penentuan kedudukan sosial, akumulasi modal dan efektivitas tindakan. Kapital simbolik adalah semua bentuk pengakuan oleh kelompok, baik secara institusional atau tidak, seperti jabatan, mobil mewah, kantor prestise, gelar, status tinggi, dan nama keluarga besar (Haryatmoko, 2010:17-18).

Teori sosial Bourdieu selanjtunya adalah arena, yang menurut sosiolog Prancis ini adalah:

a veritable social universe where, in accordance with its particular laws, there accumulates a particular form of capital and where relations of force of a particular type are exerted (Bourdieu, 1993:215).

Arena merupakan ruang pergulatan strategi manusia yang dikaitkan dengan peneguhan atau peningkatan posisi mereka sehubungan dengan akumulasi modal yang dimiliki. Dalam arena, pelaku terbagi ke kelaskelas menurut kepemilikan kapital dan habitusnya, sehingga arena merupakan medan perjuangan, baik antar individu maupun kelompok. Dalam pertarungan arena pelaku memerlukan strategi, dan hal ini tergantung pada besarnya kapital yang dimiliki serta struktur modal dalam posisinya di lingkup sosial.

Distingsi, secara bahasa adalah hal yang membedakan, ciri atau karakter khas. Sedang dalam kamus Bourdieu, distingsi adalah pola prilaku agen atau kelompok tertentu yang membedakan diri dari yang lainnya, yang berfungsi sebagai pengukuhan atas status sosial.

Social subjects, classified by their classifications, distinguish themselves by the distinctions they make, between the beautiful and the ugly, the distinguished and the vulgar, in which their position in the objective classifications is expressed or betrayed (Bourdieu, 1984:6).

Pada kelas dominan, perilaku membedakan diri terlihat sangat jelas. Bourdieu memberikan spesifikasi pola prilaku kelas dominan pada tiga hal, yaitu makanan, budaya, dan penampilan. Ketiga kategori tersebut memiliki makna dalam hubungan kekuasaan atau dominasi (Haryatmoko, 2010:19).

\section{Ruang Sosial dalam Midah Simanis Bergigi Emas}

Midah Simanis Bergigi Emas menceritakan perjuangan seorang perempuan bernama Midah dalam meraih kemandirian dan kesuksesan di ruang sosial. Midah, tokoh utama dalam cerita ini, digambarkan sebagai seorang perempuan dengan fisik manis. Dalam kehidupan keluarga orangtuanya yang awalnya "berada", ia mengalami kekerasan psikis serta fisik dan menyebabkan trauma mendalam dalam diri Midah. Akan tetapi, pengalaman buruk itu membentuk karkater jiwa yang kuat dan mandiri untuk mengarungi kehidupan. Hadji Terbus, suami pilihan bapaknya, terpaksa ia tinggalkan karena telah berlaku semena-mena dan mempunyai istri banyak. Dalam kesendirian, Midah menemukan kebebasan untuk bertindak, yaitu menyanyi lagu keroncong, yang di waktu sebelumnya, mendengarkannya saja dilarang oleh bapaknya.

Dalam keadaan hamil setelah kabur dari rumah Hadji Terbus, Midah mencari pekerjaan untuk menghidupi sang janin dan dirinya. Dengan bekal keterampilan bernyanyi, Midah mencari pekerjaan dan akhirnya bertemu rombongan musik keroncong yang merekrutnya karena memiliki skill dalam bernyanyi dan juga paras yang manis. Dalam arena rombongan keroncong, Midah juga mengalami kekerasan, baik fisik maupun psikis, dari laki-laki maupun perempuan. Tetapi kekerasan yang diterimanya itu tidak menyurutkan semangat menjalani hidup, malah menambah kemandirian dan kekuatan Midah untuk mengadu nasib dalam hidup, sampai akhirnya Midah didepak dari grup musik tersebut.

Midah lalu memutuskan bersolo karir. Ia kemudian bertemu seorang lelaki bernama Ahmad, seorang polisi yang juga seniman yang mengenalnya sekilas -karena paras Midah yang manis - saat masih bersama rombongan keroncong. Dari bantuannya, Midah bisa bernyanyi di radio setelah diajari teknik bernyanyi terlebih dahulu oleh Ahmad. Hanya saja, bantuan Ahmad itu tidak tulus. Ia menagih "balas jasa" dari Midah. Walau Midah terus menolak, Ahmad berhasil menodainya. Setelah Midah hamil, Ahmad menolak bertang-gungjawab. Dalam kekecewaan, Midah memu-tuskan untuk usaha sendiri bernyanyi di radio. Ia bahkan mampu merambah ke dunia akting. Ketenaran Midah 
menyebabkannya berekenalan dengan banyak lelaki. Midah pun merambah profesi ke dunia baru sebagai pekerja seks komersial. Keterbebasan dari kekerasan para lelaki mengantarkannya pada kebebasan dan kemandirian juga kesuksesan yang ia pilih sendiri, tanpa tekanan siapapun.

\section{Kapital-Kapital Tokoh Midah}

\section{Kapital Sosial}

Interaksi sosial Midah dengan keluarga, terutama ayahnya, mengalami pasang surut, walau secara emosional tetap terjalin. Hal tersebut setidaknya bisa dilihat dalam empat fase perjalanan hidup Midah. Pertama, fase bahagia, yaitu saat Midah kecil sampai umur 10 tahunan, saat pertalian Midah sebagai anak dan orangtuanya begitu intim dan hangat (Toer, 2010: 11). Kedua, fase renggang, yaitu saat Midah tersingkir dari perhatian dan kepedulian orangtua yang telah "dirampas" oleh adikadiknya. Hal itu menimbulkan kekecewaan yang dibalut "pemberontakan" keluar sementara dari arena keluarga, serta menciptakan habitus sendiri, yaitu menyukai lagu keroncong (Toer, 2010: 16 - 19).

Ketiga, fase rindu, yaitu saat orangtua merasakan penyesalan atas perlakuan kasar terhadap anaknya sendiri ketika remaja, serta kondisi Midah yang memprihatinkan tinggal "di jalanan" dengan membawa bayi. Orangtuanya kemudian mencari Midah dan hanya mendapatkan cucunya (Toer, 2010: 67 - 76, 97 106). Keempat, fase buruk, walau sempat kembali ke rumah orangtuanya untuk mengambil anaknya, Rodjali, dan dibujuk untuk tidak pergi lagi, Midah tetap berteguh pendirian untuk mencari arena lain dan menciptakan habitusnya sendiri dengan kapital yang telah ia punyai (Toer, 2010: 113 - 132).

Kondisi sangat kontras jika dibanding hubungan Midah dengan Riah - pembantu di rumah orangtuanya - yang terus terikat kuat sampai Midah memutuskan untuk berpisah selamanya dengan orangtuanya. Riah memberikan perlindungan saat Midah dimarahi ayahnya (Toer, 2010: 19). Saat Midah kabur dari Haji Terbus, Riah menjadi tempat mengadu dan meneduh, bukan rumah orangtuanya (Toer, 2010: 21 - 22). Selain itu, naluri keibuan Riah begitu terasa saat menasihati Midah yang sedang hamil dan penuh kekecewaan (Toer, 2010: 23 26). Riah juga tetap "memantau" Midah yang terus berpetualang sebagai penyanyi solo keroncong di depan restoran-restoran dan di radio (Toer, 2010: 62 - 63) serta melaporkan hasil pantauannya ke orangtua Midah (Toer, 2010: 97).

Pada fase berikutnya adalah Midah berinteraksi dengan rombongan keroncong. Hal tersebut merupakan bukti bahwa ia juga mampu membangun hubungan sendiri dengan dunia luar tanpa bantuan keluarga. Relasi Midah dengan rombongan keroncong didukung oleh dua modal, yaitu fisik Midah yang di atas rata-rata dan skill dalam menyanyi keroncong. Sehingga ia akhirnya didaulat sebagai penyanyi dalam rombongan keroncong jalanan tersebut (Toer, 2010:30-35), walau akhirnya didepak karena alasan tak punya alat musik dan alasan subyektif kepala rombongan (Toer, 2010: 65).

Kepiawaian Midah dalam bernyanyi keroncong dan ditunjang penampilan fisik yang menawan tidak hanya menarik rombongan tersebut, tetapi juga memikat seorang polisi yang juga seniman bernama Ahmad (Toer, 2010: 59 \& 78 - 79). Tidak hanya itu, Ahmad juga mengajarkan teknik bernyanyi dan pengetahuan not balok padanya (Toer, 2010: 81 \& 89). Selain itu, Ahmad juga memberikan tempat berteduh dan di sana pula ia berkenalan dengan nyonya rumah (Toer, 2010: 82) serta rekan-rekan Ahmad (Toer, 2010: 89). Selain itu, Midah juga berhasil menjadi penyanyi di radio berkat bantuan Ahmad, yang akhirnya "menagih balas jasa" dan menodainya walau telah menolak dengan halus (Toer, 2010: 92 - 93).

Interaksi sosial Midah dengan empat kelompok sosial di atas mempunyai pola kesamaan, yaitu sad ending. Hal ini terlihat dari keterputusan hubungan Midah dengan mereka semua di akhir cerita. Selain itu, sebab keterputusan hubungan tersebut mempunyai motif yang sama, yaitu tumbuh dari rasa kecewa Midah atas perlakuan mereka yang buruk, kecuali interaksi dengan Riah yang berakhir sebagai imbas dari keterputusan dengan orangtua. Kalau hubugan awal dengan Riah dan Ahmad begitu indah, lain halnya dengan orangtua yang putus-sambung, dan kelompok keroncong yang penuh dengan konflik perseteruan, terutama dengan Nini, pesaing Midah. 
Kepopuleran Midah sebagai penyanyi sekaligus pemain film berdampak pada arena sosial dan interaksi yang lebih besar. Tidak hanya dengan orang-orang Indonesia, bahkan profesi "terselubungnya" menjadi pintu masuk perkenalan dan interaksi yang lebih luas, yaitu dengan hartawan dari berbagai negara (Toer, 2010: 132).

\section{Kapital Budaya}

Sedari kecil Midah hidup dalam keluarga religius. Ia pernah lama mengaji pada ustazah Mariamah di kampungnya sekaligus belajar bahasa Arab. Walau demikian, hal tersebut tak membantu Midah untuk memahami lagu-lagu Umi Kalsum yang berbahasa Arab (Toer, 2010: 16). Skill Midah dalam bernyanyi keroncong merupakan satu-satunya kapital yang digunakan Midah dalam menjalani hidup dan mengarungi arena sosial setelah ia "putus hubungan" dengan keluarga dan suami. Kapital ini pula yang menjadikannya berharga karena mampu dikembangkan ke bentuk kapital-kapital lain, dan khususnya keterampilan akting yang juga merupakan kapital budaya.

\section{Kapital Ekonomi}

Midah kecil dan remaja masih mendompleng hidup pada orangtua dan suaminya, sehingga kehidupan ekonominya bisa tertopang dengan baik. Setelah berpisah dari suaminya dan menjadi penyanyi keroncong jalanan, Midah mulai membangun kapital ekonominya dari pundi-pundi yang berhasil dikumpulkan. Walau tidak seberapa, penghasilan dari jerih payah menyanyi bersama rombongan musik sebagai penyayi keroncong dapat memenuhi kebutuhan hidup sehari-hari, selain juga dapat membiayai proses persalinan anak pertamanya di rumah sakit (Toer, 2010: 55).

Kapital ekonomi Midah terus meningkat seiring dengan profesi barunya sebagai penyanyi di radio. Hal ini berdampak signifikan terhadap perekonomiannya, ditambah lagi dengan pekerjaannya sebagai aktris film (Toer, 2010: 132). Kepopuleran Midah sebagai artis merambah ke profesi "dunia malam", hingga akhirnya ia banyak dikenal kalangan hartawan dari berbagai negara, tak hanya Indonesia, tetapi juga Tionghoa, Arab, dan bangsa lainnya. Midah pun sering hidup di villa peristirahatan dengan mereka. Walau "pergulatan" dengan mereka terasa tawar dan pahit (Toer, 2010: 131), tetapi hal itu tentu menambah kuantitas dan bahkan kualitas ekonomi kehidupannya.

\section{Kapital Simbolik}

Jika ayahnya mempunyai titel haji dan kekayaan melimpah yang menempatkannya pada posisi simbolik yang tinggi di lingkungan sekitarnya, maka keindahan fisik Midah serta kepiawaiannya dalam menyanyi dan akting mampu membangkitkan kekaguman dalam benak banyak orang terutama kaum lelaki. Dunia selebritas juga menjadikannya terkenal dan populer, tidak hanya di kalangan seniman, tetapi juga kalangan hartawan kelas atas. Popularitas nama Midah melesat bersama dengan kepopulerannya dalam pergaulan dengan para lelaki. Midah pun menjelma menjadi nama dengan segala bentuk pengakuan dan pujian (Toer, 2010: 131 - 132).

\section{Pergulatan Habitus dan Kapital dalam Arena}

Kabur dari rumah orang tua dan suaminya merupakan awal babak baru kehidupan Midah dan juga awal perjuangan sejati yang tumbuh dari dalam jiwanya. Terlepas dari kehidupan serba ada yang dialaminya bersama orangtua dan suami memaksanya untuk berjuang dari nol. Modal utama yang membantunya untuk berjuang hidup adalah kapital budaya berupa kemampuan menyanyi keroncong serta modal simbolik dengan bentuk fisik yang manis dan montok.

Bakat menyanyi keroncong merupakan modal budaya yang signifikan dalam hidup Midah. Karena modal inilah yang membuka pintu harapan untuk membangun kapital lainnya sehingga bisa bertahan dalam arena dan bahkan mampu mendominasi. Kemampuan Midah bernyanyi keroncong tidak tumbuh mendadak. Tetapi kesenangan Midah pada musik merupakan efek tidak langsung dari habitus sang ayah yang sering membawa Midah kecil ke dalam arenanya yang selalu mendengarkan lagulagu Umi Kalsum, keroncong versi Arab. Sehingga ketertarikannya pada musik sudah tumbuh dalam jiwa sejak kecil (Toer, 2010: 11). Namun disebabkan rasa kecewa atas perubahan sikap orang tua, ia tak lagi menyukai habitus ayahnya tersebut, tetapi secara tidak sadar mulai 
menyenangi keroncong versi Indonesia yang menjadi habitus barunya (Toer, 2010: 16).

Ketertarikan Midah pada keroncong bermula dari pertemuannya dengan rombongan pengamen keroncong di kampung halamannya. Kesenangan pada keroncong ini tidak hanya disebabkan faktor musik belaka, tetapi juga karena faktor psikologis Midah yang mendambakan "kehangatan" juga kebebasan seperti yang terlihat dari para pengamen keroncong tersebut, mereka yang riang bercanda dan tertawa, terlepas dari segala kesulitan dan masalah hidup. Dan ini merupakan sisi kesamaan yang ingin dirasakan oleh Midah sehingga merasa bersatu dengan mereka (Toer, 2010: 17).

Midah tidak berhenti pada batas ketertarikan saja, tetapi ditindaklanjuti dengan menekuni dan mempelajarinya sehingga ketertarikan itu berubah menjadi habitus dan keterampilan diri. Keterampilan Midah menyanyi keroncong tersebut diasah secara otodidak tanpa guru dengan cara mendengarkan lagu-lagu keroncong langsung dari piringanpiringan hitam yang dibeli dari pasar Glodok. Bakat menyanyi Midah pun tumbuh dalam diri, dan lagu-lagu keroncong mampu dihafal dengan cepat. Empat piringan hitam yang memuat delapan lagu keroncong mampu dihafal langsung dengan tiak menyalahi irama dalam waktu sehari (Toer, 2010: 16-18).

Pembelotan selera musik Midah dari Umi

Kalsum kepada keroncong ala pribumi (berbahasa Indonesia) membawa berkah yang sangat berharga dalam perjalanan hidupnya menyusuri arena-arena baru setelah "terbebas" dari arena keluarga dan suami. Tuntuan untuk bertahan hidup menjadi dorongan Midah untuk mencari arena baru sehingga bisa mendapatkan pekerjaan untuk menghidupi janin dan dirinya. Dan berkat keroncong hal itu terwujud, dan berkat keroncong pula kapital ekonominya meningkat, kapital sosialnya juga meluas. Hal ini diawali dengan hubungannya dengan rombongan keroncong jalanan yang baru saat ia mencari rombongan keroncong pertama kali ditemui. Saat pertemuan inilah Midah mampu menunjukan kepiawaiannya menyanyi keroncong sehingga memikat para personel rombongan tersebut, kecuali Nini yang merasa tersaingi. Midah akhirnya didaulat menjadi penyanyi grup musik tersebut setelah mampu menunjukan skill menyanyi dan memenangkan "kontes" dengan penyanyi sebelumnya yaitu Nini yang dianggap sudah tua dan tak menjual oleh kepala rombongan keroncong, dan juga mampu menyebutkan lagu-lagu keroncong yang ia hafal setelah sang kepala rombongan dan salah satu personelnya merasa ragu akan kemampuan Midah.

\begin{abstract}
Sekarang saatnya, pikirnya. Dan setelah tersenyum memandangi rombongan itu seorang demi seorang ia pun menyanyilah dalam pantun jawaban: "Petir Cibatok menyambar tiang - Tiang besi di tengah bolong. Pikir-pikir habis dipikir memang diri diambuk keroncong [...] Suaramau begitu bagus. Setelah menunjuk perempuan setengah tua bergigi emas, ia meneruskan: Dia sudah tua, tidak menarik pendengar lagi. Suaranya pun tak sebagus engkau. Apa? Habis manis sepah dibuang! Teriak wanita bergigi emas itu. (Pramoedya, 2010: 32).
\end{abstract}

Tiba-tiba Rois, kepala rombongan, memperhatikannya lagi, bertanya: Lagu apa saja yang kau bisa? Jali-jali, Kicirkicir, Moresko, Telemoyo, Roda Dunia.... Itu sudah cukup banyak. Bengawan solo? Tanya Min mencoba-coba mematahkan cemburu hatinya. Kan setiap orang bisa menyanyikannya. (Pramoedya, 2010: 35).

Dalam menjalani karir sebagai penyanyi grup keroncong, kapital ekonomi Midah pun meningkat karena lembaran-lembaran uang kertas tidak sedikit didapat. Sehingga ia bisa membiayai sendiri proses persalinan anaknya yang pertama buah perkawinannya dengan Hadji Terbus (Toer, 2010: 55). Relasi Midah dengan rombongan keroncong menjadi buruk setelah melahirkan seorang anak. Anak yang merupakan anugerah dari Tuhan tersebut dijadiakn senjata untuk mendepakanya karena dianggap menjadi bumerang oleh anggota rombongan, terutama Nini yang ingin mendepak Midah yang kembali bergabung ke rombongan setelah terdepak, dan juga Mimin yang gagal "menidurinya" dengan alasan akan mengganggu Midah bekerja. Sampai akhirnya ia diusir karena konflik internal dengan anggota rombongan tersebut ditambah alasan tidak mempunyai kontribusi alat musik, walau sejatinya karena ia menolak tawaran menikah yang diajukan oleh ketua rombongan. 
Mana bisa kita tidur di samping orok ini, Nini melepaskan perasaannya. Lebih baik dia pergi dari rombongan, Mimin menyambung. Dengan orok itu dia takkan bisa kerja apa-apa. Aku bisa bekerja sambil menggendong anak ini, bantah Midah. Omong kosong, seru yang lain. Yang kedengaran bukan nyanyianmu, tapi tangis si orok jahannam itu! (Pramoedya, 2010: 57 \& 58).

Apa alat kau di rombongan ini? Apa! Cuma itu anak anjing, yang cuma menyusahkan kita semua [...] Aku punya biola, Mimin punya gendang, semua orang di rombongan punya alatnya sendiri-sendiri. Punya apa kau? Betina begini mesti diusir. Manis, kata kepala rombongan itu akhirnya. Dengan gigi emasmu itu engakau bertambah manis. Sayang tak mau jadi biniku. Jadi...... (Pramoedya, 2010: 64 \& 65).

Hidup di arena musik membentuk habitus baru Midah. Setelah tidak lagi dengan rombongan keroncong, setiap hari ia harus menyanyi sendiri dengan ditemani anaknya dari restoran ke restoran, depot ke depot, dan jalanan ke jalanan. Kemudian habitus barunya ini diasah dengan baik saat bersolo karir dan kemudian bertemu dengan Ahmad seorang polisi yang juga mantan seniman, yang mengenalnya sekilas saat masih bersama rombongan keroncong karena kemanisan paras Midah. Realsi sosial Midah dan Ahmad pun sangat hangat dan dekat. Ahmad mengajari Midah not balok agar kualitas menyanyi menjadi lebih baik dan meningkat. Sehingga akhirnya Midah bisa menyanyi di radio, arena yang setingkat lebih baik dari pada menyanyi di jalanan, baik dari segi ekonomi, sosial, maupun prestise profesionalitas dan popularitas. Dan hal ini tidak terlepas dari kontribusi Ahmad yang mengajarinya olah vokal, karena ia adalah mantan seniman yang tentu mempunyai banyak relasi dengan para pekerja di arena tarik suara (Toer, 2010: 81 \& 92).

Relasi Ahmad dan Midah kemudian memburuk dan terputus disebabkan penolakan Ahmad yang telah menodainya untuk bertanggungjawab atas janin yang tumbuh dalam rahim Midah. Tetapi hal ini tidak menyurutkan spirit Midah yang tertekan secara psikis, untuk bertarung dalam arena bernyanyi. Malah kepopuleran sebagai seorang penyannyi mampu diracik Midah dengan baik sehingga dapat memperluas kapital sosial, meningkatkan kapital ekonomi, dan menambah kapital budaya. Tidak hanya dalam bernyanyi, tapi mampu merambah ke dunia perfilman. Tidak hanya menambah sisi kapital budaya, tetapi juga kapital simboliknya yang ditandai oleh kepopuleran Midah sebagai penyanyi dan pemain film. Popularitas Midah menembus batas, ekonominya pun terus meningkat, juga relasi sosialnya meluas, bukan hanya dengan para pekerja seni saja, tetapi juga dengan para konglomerat papan atas, baik nasional maupun mancanegara.

\begin{abstract}
Setelah beberapa bulan lamanya nama Simanis Begigi Emas tak pernah terdengar di peralatan-peralatan atau radio, kini nama itu menggelembung dari penjuru ke penjuru. Midah dalam sepotong hidupnya yang sekarang, telah banyak bertemu lelaki pertemuan segala-galanya [...] Sekali ia hidup untuk berberapa bulan di villa peristirahatannya dengan hartawan Indonesia, Tionghoa, Arab, dan bangsa apalagi yang tidak [...] kepopuleran namanya berkuda dengan kepopulerannya dalam pergaulan dengan lelaki. Setelah studio radio menjadi gelanggangnya yang biasa, ia merambahi jalan bagu ke gelanggang film. (Pramoedya, 2010:131 - 132).
\end{abstract}

Keberhasilan dan kesuksesan Midah tersebut tidak terlepas dari kecerdikannya dalam meramu bakat menyanyi dan juga strategi menempatkannya dalam arena yang mendukung skillnya tersebut. Walau awalnya ketertarikan pada keroncong hanyalah pelampiasan atas kekecewaan, dan juga profesi menyanyi dilakukan karena tuntutan dan keterpaksaan untuk keberlangsungan hidup, tetapi pada fase berikutnya setelah kehidupannya mapan, menyanyi menjadi modal yang mampu dikonversi dengan baik oleh Midah menjadi kapital-kapital lainnya, sehingga mampu mengubah status sosial dan nasib hidupnya dalam ruang sosial.

\section{Distingsi Sebagai Simbol Perlawanan}

Prilaku membedakan diri bukan hanya domain kelas dominan, tetapi juga kelas yang terdominasi. Jika kelas dominan mener- 
jemahkannya pada pola persaingan dan pengkotakan diantara mereka untuk menegaskan status sosialnya, maka kelas lain dengan bentuk penolakan serta perlawanan terhadap ketidakadilan atau dominasi dalam ruang sosial. Dan salah satu bentuk perlawanan yang dilakukan oleh agen yang terdominasi adalah dengan menciptakan habitus yang berbeda dari habitus kelas dominan.

Pengalaman hidup Midah yang bahagia saat kanak-kanak dan berubah drastis saat menjadi remaja, serta kekerasan fisik dan mental yang menimpanya, mendorong jiwanya untuk melakukan perlawanan atas dominasi ayah dalam arena sosial keluarga. Sebagai kelompok yang terdominasi dalam keluarga, Midah berusaha keluar dan menjauhi segala hal yang disukai ayahnya. Hal itu diawali dengan bergantinya selera musik lagu Arab kepada keroncong versi pribumi, yaitu keroncong yang diharamkan sang ayah. Jika Umi Kalsum merupakan distingsi kebanggan dan kebesaran tersendiri bagi Haji Abdul di hadapan kawankawan sejawatnya, maka keroncong dalam diri Midah menjadi sebuah simbol perlawanan untuk mendapatkan kemerdekaan dan kebebasan dari arena kehidupan keluarga orang tua yang terkungkung, kaku, dan keras, dan juga di setiap ruang sosial lain yang dialaminya.

Kairo! Siapa pula di antara kawankawannya yang penakut itu pernah dengar nama itu. Itupun belum lagi habis. Masih ada kebesaran yang tidak terlawankan: bisa bercerita sambil berbisik tentang Umi Kalsum -itu biduan Mesir yang menawan hati penduduk di kampung-kampung Jakarta. (Pramoedya: 2010: 10).

Waktu ia bernyanyi untuk seorang itu ia mendapat lembaran-lembaran kertas yang tidak sedikit. Ada timbul hidup dalam jiwa Midah. Ada terbit suasana hati yang baru, yang belum pernah dialaminya selam ini -kebebasan tanpa ikatan apapun jua dalam pengabdian pada keroncong [...] Bagaimanapun ia bergerak, betapapun jua ia bertingkah, yang ada hanya kebebasan, kegairahan yang tak terartikan. (Pramoedya: 2010: 36)

Distingsi Midah yang lain terjadi pada episode kehidupan Midah selanjutnya, yaitu saat dinikahkan dengan Haji Terbus secara paksa tanpa sedikit pun restu dari jiwanya, dan kemudian mengetahui bahwa suaminya beristri banyak. Di saat wanita-wanita yang dimadu "terlena" dengan segala kapital yang dimiliki Haji Terbus dan juga nerimo lego lilo, Midah memutuskan untuk "menceraikannya" dengan keluar dari istana suaminya walau sedang mengandung janin, buah pernikahannya dengan orang kaya dari Cibatok tersebut (Toer, 2010: 21 $-22)$.

Pengalaman traumatis yang dialami Midah telah membangun habitus dan distingsi seorang perempuan yang tertanam dalam karakter jiwa yang melawan, teguh, dan kuat atas segala bentuk penindasan dalam ruang sosial yang dihadapi. Bentuk penolakan atas tawaran nikah dari kepala rombongan keroncong merupakan salah satu contohnya (Toer, 2010: 41 \& 58). Dan juga perlakuan sarkastis dari Nini, wanita pesaing dalam rombongan keroncong dihadapi oleh Midah dengan terbuka (Toer, 2010: 58 - 59). Serta tindakan Ahmad yang menolak janin buah percintaanya ditanggapi Midah dengan kata-kata yang "mendiamkan" tanpa peduli pada sikap Ahmad tersebut:

Biarlah segala yang kotor aku ambil
sebagai tanggungjawabku sendiri [...]
Tapi aku kini mengetahui bahwa seorang
yang kucintai adalah pengecut yang tidak
punya keberanian sedikitpun juga
(Pramoedya, 2010: 110).

Kekerasan yang dialami Midah menumbuhkan sikap perlawanan dan pendirian yang kuat, sehingga memaksanya harus hadapan dengan kebiasaan umum. Dan puncak dari perlawanan yang sekaligus menjadi distingsi tokoh Midah adalah "kemurtadan" dari moralitas yang sangat dijunjung tinggi oleh keluarganya yang agamis. Ia lebih memilih untuk menghambakan diri pada cinta komersil yang dijual kepada para lelaki yang haus mencari kepuasan hawa-nafsu, sembari selalu membawa cintanya pada Ahmad; cinta fanatiknya.

Kesusilaan dan ketertiban peradaban antara baik dan buruk yang dibawanya dari rumahnya, kini tidak membangkitkan pikiran lagi padanya. Dan tambah hebat rasa kangennya pada Djali, tambah sering pula ia coba untuk bertemu dengan lelaki yang sonder cinta, dapat mendesirkan darahnya (Pramoedya, 2010: 132). 


\section{KESIMPULAN}

Novel Midah, Simanis Bergigi Emas menyiratkan keberpihakan pengarang pada sosok perempuan yang mayoritas selalu menjadi agen terdominasi dalam arena. Pengarang mewakili keberpihakannya tersebut dengan tokoh Midah, perempuan yang berjuang keras menciptakan habitus-habitus baru dan juga mengembangkan kapital-kapital yang dimilikinya, serta meramunya dengan baik dalam percaturan arena yang dihadapi. Sehingga akhirnya mampu mengubah status kelas sosialnya (menjadi penyanyi dan pemain film) dengan cara pemanfaatan kapital-kapital yang dimiliki.

Melalui tokoh Midah pula pengarang memberikan gambaran solusi dan upaya penting dalam mendobrak kontruksi sosial yang diskriminatif, yaitu dengan melakukan perlawanan dan perjuangan yang dimotori kaum perempuan sendiri. Hal tersebut tersirat dari pencitraan tokoh Midah sebagai perempuan yang berjuang membebaskan diri dari penjara dominasi maskulin dan merepresentasikan sendiri apa yang ada dalam benak dan pikirannya tanpa melalui laki-laki. Dan itu tidak terwujud kecuali dengan topangan berbagai macam kapital; ilmu pengetahuan, wawasan, dan keterampilan yang

\section{DAFTAR PUSTAKA}

Bourdieu, Pierre. (1977). Outline of a Theory of Practice. Translated by Nice, Richard. London: Cambridge University Press.

Bourdieu, Pierre. (1984). Distinction: A Social Critique of the Judgment of Taste. Translated by Nice, Richard. Cambridge-Massachusetts: Harvard University Press.

Bourdieu, Pierre. (1993). The Field of Cultural Production. Randal Johnson, ed. Columbia University Press. dimiliki Midah, serta penempatan strategi cerdas dalam meramu habitus dan kapital-kapital sehingga mampu "menguasai" arena sosial.

Pilihan Midah untuk menjadi perempuan penghibur di atas ketenarannya sebagai penyanyi dan pemain film merupakan bentuk suara kebebasan yang merepresentasikan dirinya. Kekuasaan terhadap tubuh benar-benar menjadi hak mutlak dan domain perempuan sendiri walau pada aksi 'amoral' sekalipun. Tanpa ada paksaan atau tindasan sekalipun, tanpa ketakutan atas kesusilaan yang dianut oleh orang tua, tanpa paksaan persetubuhan yang dilakukan Mimin dan Ahmad, tanpa harus mengurus keluarga dan anak seperti yang dianjurkan Rois, dan tanpa kekerasan fisik yang diperbuat Hadji Terbus.

Terlepas dari keberhasilan materialistis Midah, skill yang dipilih oleh Pramoedya yaitu menyanyi dan akting seolah merepresentasikan dorongan dan keberpihakannya pada perempuan yang harus bersuara dan bertindak, sehingga mampu merepresentasikan dirinya sendiri, baik dalam lingkungan pribadi maupun sosial. Menyanyi adalah usaha mengeluarkan suara yang bernada. Dan akting merupakan gerak tindakan teratur di atas panggung. Seperti itu pula seharusnya perempuan. Bersuara dan beraksi dalam arena sosial.

Den Boef, August Hans dan Kees Snoek. (2008). Saya Ingin Lihat Semua Ini Berakhir. Depok: Komunitas Bambu.

Haryatmoko. (2010). Dominasi Penuh Muslihat. Akar Kekerasan dan Diskriminasi. Jakarta: PT. Gramedia Pustaka Utama.

Jenkins, Richard. (2010). Membaca Pikiran Pierre Bourdieu. Bantul: Kreasi Wacana.

Liu, Hong . (2008). Pram dan Cina. Depok: Komunitas Bambu.

Toer, Pramoedya Ananta. (2010). Midah, Simanis Bergigi Emas. Jakarta: Lentera Dipantara. 